DOI: https://doi.org/10.29285/actapinteriana.2017.3.93

\title{
François Euvé Penser la création comme jeu címü könyvének ismertetése.
}

\author{
Bagyinszki Péter Ágoston OFM ${ }^{\mathrm{a}}$ \& Mihálffy Zsófia \\ ${ }^{a}$ Sapientia Szerzetesi Hittudományi Főiskola, 1052 Budapest, Piarista köz 1. \\ bagyinszki.agoston@sapientia.hu
}

Bagyinszki P. Á. \& Mihálffy Zs. (2017): François Euvé Penser la création comme jeu címü könyvének ismertetése. A review of the book Penser la création comme jeu by François Euvé. Acta Pintériana, 3, 93-94.

Van olyan racionalizmus, amely eltompítja az ember spirituális érzékenységét. Ám ugyanígy, az intellektusnak vannak olyan ludikus (játékos) készségei is, amelyek élesítik az ember lelki-szellemi fogékonyságát. Természettudományos és teológiai müveltséggel egyaránt rendelkező kortársaink nemegyszer felteszik a kérdést: Vajon milyen módon lehetne kilazítani a természettudományos és a teológiai gondolkodást egymástól elkülönítő berozsdásodott, ódon zárakat? François Euvé szerint a párbeszéd egy „ludikus kulcs” megtalálásával nyerhetne új lendületet. A fizikusi előtanulmányokkal felvértezett francia jezsuita doktori disszertációjában egy ilyen játékelvü teológiai paradigma körvonalazására vállalkozott: François Euvé, Penser la création comme jeu, Paris, Éditions du Cerf, "Cogitatio fidei, n 219", 2000, 412 p.
„A játék tétje - mely játékra mindig a halállal való civakodásként kell tekintenünk - nem szabad, hogy elfeledtesse velünk azt az örömet, amit minden játék magában hordoz. A reményt a világra való rácsodálkozás táplálja. A teremtésben jelen van a játék, hiszen a megígért és remélt jövő a választottak 'táncában' bontakozik ki. Magunk mögött hagyva a bejárt utat és a leküzdött akadályokat, az igaz ember játszó és nevetö gyermekké válik.” (386. o.)

Ez a játékélmény jelenti a francia szerző kiindulópontját.

François Euvé emelkedett akadémiai stílusban, nagy erudícióval, három részre tagolt $3 \times 3$ fejezetben fejti ki gondolatmenetét a ludikus paradigma alapjára helyezett interdiszciplináris párbeszéd új lehetőségeit illetően, miközben elsősorban a katolikus teológus szempontjából végzi el a szükséges elemzőmunkát.

Az első részhez tartozó három fejezet azt a kérdést járja körül, hogy: „Miért hasznos ma a játék szimbolizmusa a teremtés teológiájában?" Először is észre kell vennünk, hogy az utóbbi évszázadokban a „teremtett világhoz”, illetve a „természethez” füződő viszonyunk a természettudományok előretörése nyomán lényegesen megváltozott. Ez a változás a teremtés teológiájával foglalkozó diskurzust szorosan érinti. Ma már azt a pozitivista-determinista tudományszemléletet is meghaladtuk, amely a 19. század tudományosságát uralta. A teológia előnyt kovácsolhat a természettudományos diskurzusban fel-felbukkanó „ludikus hermeneutikai kulcs” körültekintő alkalmazásából, mert ennek a hagyományos teremtéstanban is megvannak a gyökerei (vö. 1. f.). A második ezredfordulóra a teológia interdiszciplináris kapcsolatrendszere is átalakult. Euvé a közismert négyrétủ tipológiából kiindulva mutatja be ennek a kapcsolatrendszernek az eltérö megközelítéseit: a konfliktus, a függetlenség, a dialógus, valamint az integráció igényének mozzanatai egyaránt jelen vannak ebben a kapcsolatban. A II. Vatikáni Zsinat kifejezésével élve, az „idők jeleit” ismerhetjük fel abban a folyamatban, amely a szembenállások hangsúlyozásától a konvergens 
mozzanatok felismerése felé, illetve a „kritikai dialógus” gyakorlatának irányába halad. (vö. 2. f.) Euvé ezt követően összegzi a teremtéshit alapjait és bemutatja a creatio ex nihilo gondolat fontosságát, már előrevetítve ezzel a ludikus kulcs teológiai alkalmazásának a lehetőségeit. (vö. 3. f.)

A második részhez tartozó három fejezetben Euvé áttekinti a ludikus kulcs használatát megalapozó gazdag hagyományanyagot. A szerzőt az aktualizálás érdekli, ezért nem kronológiai sorrendben halad. Először bemutatja a ludikus kulcshoz kapcsolódó (vagyis a játékszimbolizmust alkalmazó) kortárs diskurzust (vö. 4. f.), majd a Péld 8,30-31 nyomán rámutat a biblikus teológiai és görög alapokra (vö. 5. f.), végül áttekinti a releváns patrisztikus és skolasztikus hagyományt (vö. 6. f.). Mivel a tárgyalás az utóbbi két fejezetben főleg Hugo Rahner magyarul is olvasható „A játszó ember” címü mủvére támaszkodik (Kairosz, Budapest, 2013), ezért ennek a rendkívül gazdag hagyományanyagnak az ismertetésére itt nem szükséges kitérnünk. Figyelemre méltó azonban, ahogy például Hitvalló Maximoszról, Eckhart mesterről és Alfonz Rodriguezről további bőséges saját forrásanyagot vonultat fel. Euvé szerint a játékhagyománynak ez a gyökérzete erősen inspirálja és biztos alapokra helyezi a ludikus kulcs kortárs alkalmazásait. Arra vonatkozóan, hogy a nyugati ludikus hagyomány hogyan és mely szerzőkön keresztül lép be a kortárs szekuláris és teológiai diskurzusba, Euvé tárgyalásával tartalmilag megegyező áttekintéssel szolgál Bagyinszki Ágoston „A húsvéti gyertya fényjátéka” címü tanulmányában (in 11 Praeconia 2016/2). Johan Huizinga „Homo ludens” címủ könyve időtálló alapműve a kapcsolódó szaktudományos diskurzusnak.

A harmadik részhez tartozó három fejezetben a francia szerző már nem kérdés formájában, hanem tételmondatként fogalmazza meg a mondanivalóját: „Közelítsünk a teremtéshez a játék jegyében!” Euvé itt pontosítja és kontextualizálja a saját játékfelfogását. Először a definíciós kérdést járja körül (vö. 7. f.), majd tudományelméleti (vö. 8. f.) és teremtésteológiai (vö. 9. f.) összefüggésben bontja ki a ludikus kulcs alkalmazásának a lehetőségeit. Euvé rámutat a „pánludizmusnak”, valamint a Teremtő Isten alkotói cselekedetére alkalmazott ludikus megközelítésnek a korlátaira is, mielőtt megerösítené a ludikus kulcs fontos szerepére vonatkozó alaptételét.

Jean-Michel Maldamé, a természettudomány és teológia közti párbeszéd neves domonkos szakértője, a következőképpen értékeli az itt recenzált könyvünket:

„Euvé munkája módszerét tekintve ugyanannyira konzervatív, mint amennyire újszerü a vizsgált témáját tekintve. Ez a (ludikus) teológia egyrészt mélyen gyökerezik a patrisztikus írásokban és hagyományban, másrészt párbeszédet folytat a kortárs kultúrával: filozófiával, szociológiával és természettudományokkal. Euvé azáltal kívánja megújitani a teológiát, hogy kiemeli egy bizonyos racionalizmus csapdájából. Termékeny módon köti össze a teremtés és az üdvösség gondolatköreit."

Végezetül idézzük magát Euvét könyvének egy olyan pontján, amely mintegy a szerző ars poeticájaként fogható fel:

„A teológia nem csupán az összecsengő külső körülmények miatt érdeklödik a játék iránt. Valójában belülröl is felébred benne a vágy, hogy válaszoljon a jelen kérdéseire. Ezt a vágyat nem szabad elfojtani. A teológiának nem szabad idegenkednie a jelen adottságaitól, hanem el kell fogadnia azokat a maguk valójában, minden esetleges bennük lévö ellentmondással együtt. Ez az elfogadás ugyanolyan intenzív hatóerő, mint az érintett témák erös történeti dimenziójának kötelmei. A játék azóta foglalkoztatja a teológiai gondolkodást, amióta Izrael vénei az Isten lábainál játszó, emberek közt jelen lévö Bölcsességröl elmélkedtek. A ludikus szellemiség csak olyan teológiának lehet sajátja, amely felhagy a szigorúan zárt rendszerek kialakitásának kényszerével." (384. o.) 